\section{Salud Pública: nueva sección \\ de Educación Médica ${ }^{a}$}

La salud pública, que no es una forma de denominar la sanidad financiada públicamente, se presta a un uso digamos que fetichista cuando se habla de las políticas de salud. En parte es un recurso retórico del discurso sanitario, con el que, a modo de jaculatoria, acostumbramos a evocar la receta del bálsamo de Fierabrás para el sistema sanitario español que, en un abrir y cerrar de ojos, puede pasar de ser uno de los mejores del mundo mundial a convertirse en el tenebroso mar de la incertidumbre, rebosante de pérfidos escualos que amenazan nuestro sopor de ahítos ciudadanos. Pero en parte también es una manera de ver las cosas de la salud -los problemas y necesidades y también las eventuales soluciones o mejoras- bajo una perspectiva global. En efecto, si la salud pública tiene alguna característica genuinamente propia es la de considerar los problemas y las intervenciones sobre la salud mediante el enfoque de la población como unidad de análisis y de actuación.

El término salud pública tiene distintas acepciones ${ }^{1}$. Según una de ellas se considera un componente de los sistemas sanitarios que acostumbra a ocuparse de proporcionar servicios colectivos a comunidades y poblaciones, sobre todo servicios de protección de la salud -que incluyen las actividades de saneamiento y para algunos las intervenciones y programas de prevención de enfermedades cuando tienen como objetivo grupos de personas- y de promoción de la salud, mediante los cuáles se trata de facilitar la emancipación de la ciudadanía en aquellas cuestiones relativas a su salud y, particularmente, a la mejora o incremento de la salud que es algo más y distinto que la mera ausencia de enfermedad. Precisamente la promoción de la salud, aunque sea bajo el aspecto limitado de la Educación para la Salud ha sido objeto de análisis y recomendaciones desde la perspectiva de la formación ${ }^{2}$.

Tradicionalmente, los servicios de salud pública incorporan la vigilancia epidemiológica y el control de los brotes epidémicos y, a veces, la función de apoyo a la planificación sanitaria, mediante el análisis de la importancia de los problemas de salud y sus determinantes, y, desde luego, de su vulnerabilidad a las intervenciones.

Aunque algunos especialistas en medicina del trabajo llegan a considerar la salud pública como una rama de su especialidad, no hay duda que la salud laboral es uno de los campos de aplicación genuinos de la salud pública, no

\section{Public Health: a new section in Educación Médica ${ }^{a}$}

Public Health, not being a new denomination for the health care financed with public resources, is often subjected to a kind of fetishist utilization when dealing with health policies. This perverse utilization constitutes a rhetoric trick of the political discourse, a litany that as a panacea could transform instantly the Spanish health system from one of the best into a dangerous and uncertain environment. But Public Health is also a way to look at the problems and needs as well as the solutions and improvements in health. In fact, if Public Health has any unique trait this is the population approach to deal with the health problems and interventions.

Public Health $(\mathrm{PH})$ has different meanings ${ }^{1}$. According to one of them, $\mathrm{PH}$ constitutes a component of the health systems in charge of providing collective services to populations and communities, specially health protection (sanitation and disease prevention) and health promotion services, by which the citizenship should improve its health status, something different than just avoiding illness. Health promotion under the limited perspective of Health Education has recently been analyzed and recommendations have been advanced by an expert group in Spain ${ }^{2}$.

Usually, PH services include the epidemiological surveillance and epidemic outbreaks control and, sometimes, the function of support to the sanitary planning, through the analysis of the importance of the problems of health and determining theirs, and, undoubtedly, of their vulnerability to the interventions.

Although some specialists in Occupational Medicine manage to consider $\mathrm{PH}$ like a branch of its specialty, there is not doubt that the occupational health is one of the genuine fields of application of $\mathrm{PH}$, not only for historical reasons but especially because working environment is one of the basic environments in which we, the human beings, live.

But public health also can be understood broadly as the organized efforts of the society to improve, to sustain or to reinstate the health of the populations, so that medicine would be included in this definition, with many other professions and disciplines; undoubtedly the pharmacy and the veterinary science with the nursing -as traditional sanitary professions recognized in the law of ordering of the sanitary professions beside the odontology, the die-

a. Agradezco las sugerencias de Ildefonso Hernández y de Fernando G. Benavides. Procede la eximente habitual.

a. Thanks are due to Ildefonso Hernández and Fernando G. Benavides. 
sólo por razones históricas sino sobre todo porque el medio laboral es uno de los entornos básicos del ambiente en el que vivimos los seres humanos.

Pero la salud pública también puede entenderse como algo más amplio, los esfuerzos organizados de la sociedad para mejorar, mantener o restablecer la salud de las poblaciones, de manera que la medicina quedaría incluida en esta definición, con muchas otras profesiones y disciplinas; desde luego la farmacia y la veterinaria con la enfermería -como profesiones sanitarias tradicionales reconocidas en la ley de ordenación de las profesiones sanitarias junto a la odontología, la dietética, la podología y la fisioterapia- aunque, dada la importancia de los determinantes biológicos, ambientales -desde el punto de vista del entorno geográfico-y culturales, tanto la biología, como la ecología y la psicología, la antropología, la demografía, la sociología o la economía y, desde luego, la jurisprudencia, el urbanismo o la politicología proporcionan elementos imprescindibles para las intervenciones de la salud pública. Sin olvidar las disciplinas más instrumentales entre las que sobresale la epidemiología -que nace directamente de la salud pública - la estadística, la informática o la comunicación social.

Ocurre pues que la salud pública puede verse como un conjunto multidisciplinar y hasta multiprofesional abigarrado y complejo, de manera que se ha llegado a proponer un proceso de reconstrucción de las muchas profesiones implicadas con el propósito de alumbrar una nueva perspectiva global e integradora, un planteamiento difícil de llevar a la práctica en una sociedad polarizada hacía la especialización.

Sin embargo, la existencia de una sociedad profesional como la Sociedad Española de Salud Pública y Administración Sanitaria (SESPAS) ${ }^{3}$ pretende acoger y, en cierta forma, facilitar la convergencia de tantas disciplinas y profesiones bajo el interés común de mejorar la salud de la población y, por ello, también de la sanidad.

La fortuna de la salud pública en la retórica sanitaria no se corresponde con la asignación de recursos que los sistemas sanitarios le atribuyen y que en el conjunto de los países de la OECD se estima que viene a significar un 2'9\% del presupuesto sanitario, que en España sería el 1'3\% del gasto corriente ${ }^{4}$, en el que se incluye el coste de las vacunas del calendario oficial.

Tampoco es muy halagüeña la atención que los planes de estudios de las carreras universitarias en ciencias de la salud le dispensan, ni la relevancia que tiene en el ámbito de la formación postgraduada con apenas setenta plazas acreditadas de MIR por año. Cierto es que otras especialidades todavía resultan peor paradas, como le ocurre a la Medicina Familiar y Comunitaria que, huérfana de área de conocimiento, no dispone de cátedras ni de depar- tetics, the podiatry and the physiotherapy- although, given the importance of the determiners biological, environmental -from the point of view of the geographical environment-and cultural, the biology, as well as the ecology and the psychology, the anthropology, the demography, the sociology or the economy and also, the jurisprudence, the urban planning or social policies provide indispensable elements for the interventions of the $\mathrm{PH}$. Without forgetting the most instrumental disciplines among which the epidemiology -that it is born of the public health directly - stands out the statistics, the computer science or the social communication.

It occurs then that $\mathrm{PH}$ can be seen as a variegated and complex multidisciplinary and even multiprofessional set, so that it has been proposed a process of reconstruction of the many professions implied in order to illuminate a new global and integrated perspective, an approach difficult to bring in practice in a society polarized towards specialization.

However, the existence of a professional association like the Spanish Society of Public Health and Sanitary Administration (SESPAS) ${ }^{3}$ intends to accommodate and, in a certain way, to facilitate the convergence of so many disciplines and professions under the common interest of improving the health of the population and, because of that, also of the health system.

The fortune of $\mathrm{PH}$ in the sanitary rhetoric does not correspond with the allowance of resources that the health systems attribute it and which in the set of the countries of the $\mathrm{OECD}^{4}$ it is estimated that it comes to mean one 2 '9\% of the health budget, that in Spain it would be on $13 \%$ of the ordinary expense, in which the cost of the vaccines of the official calendar is included.

Either it is much flattering the attention that the plans of studies of the university careers in health sciences exempt for it, nor the significance that it has in the area of the training postgraduate with great difficulty seventy posts accredited of MIR by year. Some it is that other specialties are still worse stopped, as it occurs it in the Family and Community Medicine that, orphan of knowledge area, does not order of chairs nor of University departments own. Although, how it is obvious, the occupation of educational structures has a right sense -in the society as a whole rather than in the corporative one -- in so far as it implies bringing knowledge and solutions, which can be made, how the doctors of family have demonstrated, from out of the university.

But perhaps the little interest of the students for whom, in general, the public health continues being one of the "marías" (marginal subjects) of the curriculum, in spite of its frequent changes of name, from the denomination, is still more worrisome more rancid than classical, of 
tamentos universitarios propios. Aunque, como es obvio, la ocupación de estructuras docentes tiene un sentido -en el ámbito de la sociedad, no en el corporativo -- en la medida que supone aportar conocimientos y soluciones, lo cual puede hacerse, como han demostrado los médicos de familia, desde fuera de la universidad.

Pero tal vez sea más preocupante aún el poco interés de los estudiantes para los que, en general, la salud pública sigue siendo una de las "marías" del curriculum, a pesar de sus frecuentes cambios de nombre, desde la denominación, más rancia que clásica, de higiene, a las formulaciones de salud comunitaria, medicina social, medicina preventiva y tantas otras que se han ensayado. Desinterés que no parece haber cambiado sustancialmente con la incorporación de materias instrumentales como la estadística y la epidemiología, aunque su uso en la investigación sanitaria y clínica sea creciente.

Nada de ello es ajeno a la evolución de la salud pública en los sistemas sanitarios y, particularmente a su tradicional supeditación a las estructuras de la administración gubernamental, lo que, entre otras cosas, ha impedido un desarrollo profesional independiente ${ }^{5}$. Así pues, tanto desde el punto de vista del ejercicio profesional como del de su aprendizaje y la organización de la formación, la salud pública está inmersa en una formidable crisis que, como siempre, implica múltiples oportunidades, una de las cuales es el desarrollo del espacio europeo de educación superior ${ }^{6}$.

En cualquier caso las potencialidades de la salud pública como estímulo para la reorientación de la sanidad no son en absoluto despreciables, configurando un terreno que, en el contexto actual de incertidumbre sobre la viabilidad misma de los sistemas sanitarios, no puede dejar de explorarse ${ }^{7}$. Valoración que no comparten algunos ilustres salubristas para los que una relación demasiado estrecha con la asistencia sanitaria sería el abrazo del oso que podría sepultar definitivamente la perspectiva poblacional de la salud pública ${ }^{8}$.

La nueva sección que la revista ha decidido crear tiene entre sus propósitos describir y analizar la formación que sobre los distintos aspectos de la salud pública actualmente se proporciona a los profesionales de las diversas "ciencias de la salud" (formación de postgrado y continuada) y a los estudiantes de las distintas titulaciones sanitarias, particularmente en relación con las propuestas de competencias que las sociedades profesionales han desarrollado ${ }^{9}$; fomentar la investigación de cuestiones clave, como las razones de la motivación y de la desmotivación de los aprendices en ciencias de la salud, o la frecuencia y la calidad de las experiencias asociadas a la intervención y a la evaluación en el ámbito de la salud comunitaria que proporcionen material original para ser publicado, o si el hygiene, to the formulations of community health, social medicine, preventive medicine and so many other that have trained. A lack of interest which it not seems to have increased substantially with the incorporation of instrumental subjects like the statistics and the epidemiology, even though its use in the sanitary and clinical research is increasing.

Nothing of this is foreign to the evolution of the public health in the sanitary systems and, particularly in its traditional subjection on the structures of the governmental administration, the one that, among other things, has blocked an independent professional development. So, from the point of view of the professional exercise as ${ }^{5}$ well as of that of its learning and the organization of the training, the public health is immersed in a formidable crisis that, how, it always implies multiple opportunities, some of which the development of the European space is from upper education ${ }^{6}$.

Nowadays, the potentiality of the public health as a stimulus for the re-orientation of the health is not at all despicable, configuring a terrain that, in the context of uncertainty about the same feasibility of the sanitary systems, can not stop being explored ${ }^{7}$. Appraisal that some distinguished public health scholars for which a too narrow relationship with the sanitary assistance would be the embrace of the bear that it could bury do not share definitively the population prospect of the public health ${ }^{8}$.

The new section which the magazine has decided to create has among its purposes describing and analyzing the training that about the different aspects of the public health is at present provided to the professionals of the several "health sciences" (education of postgraduate course and continued) and the students of the different sanitary qualifications, particularly in relation to the proposals of competences that the scientific societies have developed ${ }^{9}$; fostering the research of key questions, like the reasons of the motivation and of the lack of motivation of the trainees in health sciences, or the frequency and the quality of the experiences associated with the intervention and with the evaluation in the area of the community health that they provide original material to be published, or if the training and the training of the researchers through the programs of postgraduate course it combines effectively the social significance with the scientific excellence ${ }^{10}$ and, of course, to bring up proposals of development of the public health as a delivery substantive of the education of the students and the professionals of the "health sciences". Serve, then, this paper as call for the authors who wish to share their experiences and appraisals in any of the areas of the formation of the public health. 
adiestramiento y la formación de los investigadores mediante los programas de postgrado combina efectivamente la relevancia social con la excelencia científica ${ }^{10} \mathrm{y}$, desde luego, plantear propuestas de desarrollo de la salud pública como parte sustantiva de la formación de los estudiantes y los profesionales de las "ciencias de la salud". Sirva, pues, este artículo a modo de convocatoria para los autores que deseen compartir sus experiencias y valoraciones en cualquiera de los ámbitos de la formación de la salud pública.

Andreu Segura

\section{BIBLIOGRAFÍA}

1. Segura A. La salud pública y las políticas de salud. Política y Sociedad 2000; 35: 55-64.

2. Consejo Interterritorial del Sistema Navional de Salud. Formación en Promoción y Educación para la Salud. Madrid: Ministerio de Sanidad y Consumo, 2003. (Informe de un grupo de trabajo).

3. www.sespas.es

4. OECD. Health at a glance. OECD Indicators 2005. Paris: OECD Publishing, 2005: 73.

5. Segura A. Salud pública, política y administración: ¿rehenes o cómplices? Gac Sanit 2002; 16: 205-8.

6. Benavides FG, Bolumar F, Gómez L. El espacio europeo de educación superior, una gran oportunidad para la salud pública. Gac Sanit 2006; 20:89-90.

7. Repullo JR, Segura A. Salud Pública y sostenibilidad de los sistemas públicos de salud. Rev Esp Salud Pública 2006; 80: 475-82.

8. Alvarez Dardet C. La Salud Pública, el estado y la medicina: ¿amistades peligrosas? En: Anónimo. Competencias profesionales en salud pública. Barcelona: Institut Universitari de Salut Pública, 2000: 57-65.

9. Benavides FG, Moya C, Segura A, de la Puente ML, Porta M, Amela C (y el grupo de trabajo). Las competencias profesionales en salud pública. Gac Sanit 2006; 20: 239-43.

10. Barros AJD, Ventura R. Evaluation of graduate studies in public health in Brazil. Cad Saúde Pública 2007; 23:254-5. 